\title{
Risk of HBV infection among male and female first-time blood donors born before and after the July 1986 HBV vaccination program in Taiwan
}

Hsuan-Hui Wang ${ }^{1}$, Shu-Lung Sun ${ }^{2}$, Rong-Chiou Jau' ${ }^{1}$ Disline Manli Tantoh ${ }^{3,4}$, Shu-Yi Hsu', Oswald Ndi Nfor ${ }^{4}$, Pei-Hsin Chen ${ }^{4}$, Wen-Hsiu Liu ${ }^{4}$, Jiunn-Liang Ko ${ }^{5,6^{*}}$ and Yung-Po Liaw ${ }^{3,4,7^{*}}$

\begin{abstract}
Background: In July 1984, Taiwan officially began a nationwide hepatitis B virus (HBV) vaccination program where only infants born to HBsAg-positive mothers were vaccinated free of charge until June 1986. However, from July 1986, all infants were vaccinated against HBV. The impact of the July 1986 HBV vaccination program on first-time blood donors has not been exhaustively studied. We, therefore, determined the risk of HBV among male and female first-time blood donors born before and after the July 1986 HBV vaccination program in Taiwan.
\end{abstract}

Methods: Initially, we recruited 857,310 first-time blood donors whose data were collected between 2013 and 2018 from 5 blood donation centers in Taiwan. However, we excluded donors with incomplete and outlying data $(n=$ 12,213) and those born between July 1984 and June $1986(n=21,054)$. The final study participants comprised 9118 HBV positive and 814,925 HBV negative individuals. We divided the participants into two birth cohorts (born before and after July 1986) and assumed that those born before July 1986 were not vaccinated at birth while those born after July 1986 were vaccinated.

Results: The prevalence of HBV among those born before and after July 1986 was 4.53 and $0.25 \%$, respectively. Individuals born after July 1986 had a lower risk of HBV than those born before July 1986 . The adjusted odds ratio (OR), 95\% confidence interval (CI) was 0.16, 0.13-0.19. Men had a higher risk of HBV than women (OR $=1.40,95 \%$ $\mathrm{Cl}=1.34-1.47$ ). The interaction between sex and birth date was significant ( $p$-value $=0.0067$ ). Stratification of participants by birth date revealed a higher risk of HBV in men compared to women in both birth cohorts. The OR, 95\% Cl was 1.47, 1.40-1.55 for those born before July 1986 but declined to 1.15, 1.02-1.29 for those born after July 1986.

Conclusions: The risk of HBV was lower among those born after than those born before the July 1986 vaccination program. In both cohorts, the risk was high in men relative to women. The seemingly protective effect among those born after July 1986 was higher in women than men.

Keywords: HBV vaccination, Sex, First-time blood donor, Taiwan blood Services Foundation, HBV risk

* Correspondence: jlko@csmu.edu.tw; Liawyp@csmu.edu.tw

${ }^{5}$ Institute of Medicine, Chung Shan Medical University, No. 110, Sec. 1

Jianguo N. Rd, Taichung 40201, Taiwan

Full list of author information is available at the end of the article

(c) The Author(s). 2021 Open Access This article is licensed under a Creative Commons Attribution 4.0 International License, which permits use, sharing, adaptation, distribution and reproduction in any medium or format, as long as you give appropriate credit to the original author(s) and the source, provide a link to the Creative Commons licence, and indicate if changes were made. The images or other third party material in this article are included in the article's Creative Commons licence, unless indicated otherwise in a credit line to the material. If material is not included in the article's Creative Commons licence and your intended use is not permitted by statutory regulation or exceeds the permitted use, you will need to obtain permission directly from the copyright holder. To view a copy of this licence, visit http://creativecommons.org/licenses/by/4.0/ The Creative Commons Public Domain Dedication waiver (http://creativecommons.org/publicdomain/zero/1.0/) applies to the data made available in this article, unless otherwise stated in a credit line to the data. 


\section{Background}

Viral hepatitis heightens the susceptibility to hepatocellular carcinoma (HCC) and chronic liver disease [1]. HBV infection is an important global public health problem, accounting for significant morbidity and mortality [2]. HBV infection remains an important transfusiontransmitted disease in Taiwan due to its high prevalence [3]. Universal vaccination programs have led to significant decreases in the proportion of people living with chronic HBV [4] as well as HBV-related morbidity and mortality $[5,6]$. For example, young Chinese blood donors who were vaccinated before age 18 had a lower risk of HBV than those who were not vaccinated [7].

Before the introduction of mass HBV vaccination in Taiwan, approximately $15-20 \%$ of the general Taiwanese population tested positive for the HBV surface antigen (HBsAg), primarily because of vertical transmission [8-10]. In July 1984, Taiwan officially began a nationwide HBV vaccination program where only infants born to $\mathrm{HBsAg}$ positive mothers were vaccinated free of charge until June 1986 [11]. However, from July 1986, all infants, irrespective of their mothers' HBV status, were immunized against $\mathrm{HBV}$ with a $5 \mu \mathrm{g}$ four-dose (administered at birth, 1,2 , and 12 months) plasma-derived vaccine [12]. Neonates born to highly infected mothers also received $0.5 \mathrm{~mL}$ of the HBV immunoglobulin within $24 \mathrm{~h}$ of birth [13]. The implementation of this nationwide vaccination program led to a substantial decline in HBV infection. For instance, the chronic HBV infection rate decreased from 9.7\% among university students born before June 1974 to $<1 \%$ among those born after 1992 [14]. Moreover, the HBsAg-positive rate decreased from approximately $4.2 \%$ among university students born before 1984 to $0.6 \%$ among those born in 1999 [14].

$\mathrm{HBV}$ vaccination at birth could improve the safety of both donors and recipients during blood donation and transfusion. Several factors influence the effectiveness of vaccines. For instance, increasing age, male sex, and BMI $\geq$ 25 were associated with a lower immune response to HBV vaccination [15]. Undertaking a nucleic amplification test (NAT) for HBV during blood donation screening could improve safety during blood transfusion [7]. Blood group screening is a mandatory process in blood donation and transfusion because certain blood groups influence the pathogenesis of $\mathrm{HBV}$ and other transfusiontransmitted infections [16, 17]. Blood group antigens influence the transmission of viruses and other infectious agents by modulating the inflammatory and immune responses or by acting as ligands and receptors for such agents [18-21]. For instance, some ABO antigens are capable of blocking the binding of transfusion-transmitted disease-causing organisms to polysaccharides on the host's cells while others are not [22]. For HBV, Blood group O carriers have been found with a higher risk of infection than other blood group carriers [23].
A sufficient supply of safe blood to patients is an integral part of a country's health care policy [24]. However, statistics from the Department of Household Registration, Ministry of Interior, indicate a shift in the population structure of Taiwan from a younger to an older generation [25]. This shift could adversely affect the demographic profile of first-time blood donors. It is, therefore, important to increase the proportion of firsttime blood donors, particularly young people. The impact of the July 1986 national HBV vaccination program on first-time blood donors has not been systematically reported. The purpose of this study was to estimate the prevalence of and factors associated with HBV infection from 2013 to 2018 in male and female first-time blood donors who were born before and after the July 1986 HBV vaccination program in Taiwan.

\section{Materials and methods}

Data were collected by the Taiwan Blood Services Foundation (TBSF) from 2013 to 2018. All volunteers filled and signed a blood donation registration form before donating blood. Some of the information included sex, height, weight, birth date, permanent address, and occupation. The eligibility criteria included age, 17 to 65 years old; male body weight and hemoglobin $(\mathrm{Hb})$ level, $\geq 50 \mathrm{~kg}$ and $\geq 13.0 \mathrm{~g} / \mathrm{dL}$, respectively; female body weight and $\mathrm{Hb}$ level, $\geq 45 \mathrm{~kg}$ and $\geq 12.0 \mathrm{~g} / \mathrm{dL}$, respectively; systolic blood pressure (SBP), 90 to $160 \mathrm{mmHg}$; and diastolic blood pressure (DBP), 50 to $95 \mathrm{mmHg}$. These eligibility criteria correspond to the blood donation service requirements.

For allogeneic use, all donors underwent screening for the ABO blood type, rhesus (Rh) status, and transfusiontransmitted viral infection (TTVI) markers, such as HBsAg, HBV DNA, hepatitis C virus (HCV) RNA, human immunodeficiency virus (HIV) RNA, anti-HCV, anti-HIV, anti-HTLV-I/II antibodies to safeguard patients' health. Any blood sample which tested positive for TTVIs or had abnormal levels of alanine aminotransferase (ALT) was discarded. Medications like etretinate, non-steroid antiinflammation drug (NSAID), and antiplatelet drugs (e.g., aspirin) are potentially harmful to blood recipients or developing fetuses. So, all blood samples from donors taking such medications were discarded because such donors were considered high-risk individuals.

\section{Study population}

We recruited 857,310 first-time blood donors from 5 blood donation centers in Taiwan. We excluded donors with outlying and incomplete data $(n=12,213)$, as well as those born between July 1984 and June $1986(n=$ $21,054)$. The final sample size $(n=824,043)$ consisted of 9118 HBV positive and 814,925 HBV negative individuals. Because all infants were immunized against HBV 
from July 1986, we divided the study population into two birth cohorts (born before and after the July 1986 HBV vaccination program). We assumed that those born before July 1986 (excluding July 1984 to June 1986) were not vaccinated at birth while those born after July 1986 were vaccinated at birth. The enrolment flowchart is shown in Fig. 1.

We also grouped participants into seven areas based on their residential addresses. The northern areas comprised Taipei, New Taipei, Keelung, and Yilan; the north-central areas included Taoyuan, Hsinchu Cities, and Miaoli; the central areas included Taichung City, Changhua, and Nantou; the central-southern areas consisted of Yunlin, Chiayi Cities and, Tainan; the southern areas comprised Kaohsiung and Pingtung, the eastern areas included Hualien and Taitung; while the island areas included Penghu, Kinmen, and Matsu. All methods were carried out following relevant guidelines and regulations. Ethical approval was obtained from the Ethical Review Board of the Taiwan Blood Services Foundation (PM-108-TC-197).

\section{Laboratory testing}

Screening for $\mathrm{HBV}, \mathrm{HCV}$, and human immunodeficiency virus (HIV) was done by NAT using the Procleix Ultrio Plus assay (Grifols, CA, USA) on the Procleix Tigris platform (Grifols, New Hampshire, USA). All blood samples were initially screened in pools of eight. If blood samples from any pool tested positive for an infection, individual testing of all the samples in that pool was performed to check which sample was positive. Afterward, discriminatory NAT for HBV was performed to confirm the positive and negative donors. We defined an HBV infection as a positive HBV NAT. We used NAT to determine HBV status because NAT can detect an HBV infection even during the window period [26]. Moreover, it is good for detecting occult HBV infections [27].

\section{Statistical analysis}

We compared the differences in discrete and continuous variables between the birth cohorts (born before and after July 1986) using the Chi-square and t-test, respectively. We determined the risk of HBV infection using univariate and multivariate logistic regression analysis. We also determined the interaction between birth date and sex on HBV infection using logistic regression analysis. It should be noted that we examined only the birth date/sex interaction in this study. Therefore, other interactions were not examined systematically. In the multivariate logistic regression analyses, we made adjustments for covariates including sex, age, blood type, BMI, ALT, residential area, and occupation. The odds ratios (ORs) at $95 \% \mathrm{CI}$ were estimated. All the statistical analyses were performed using the statistical analysis system (SAS) software, version 9.4.

Enrolment

First-time blood donors in Taiwan from 2013 to 2018 $\mathrm{n}=857,310$

\section{Exclusion criteria}

Incomplete and outlying data $(\mathrm{n}=12,213)$

Born between July 1984 and June $1986(\mathrm{n}=21,054)$

Total excluded $(\mathrm{n}=33,267)$

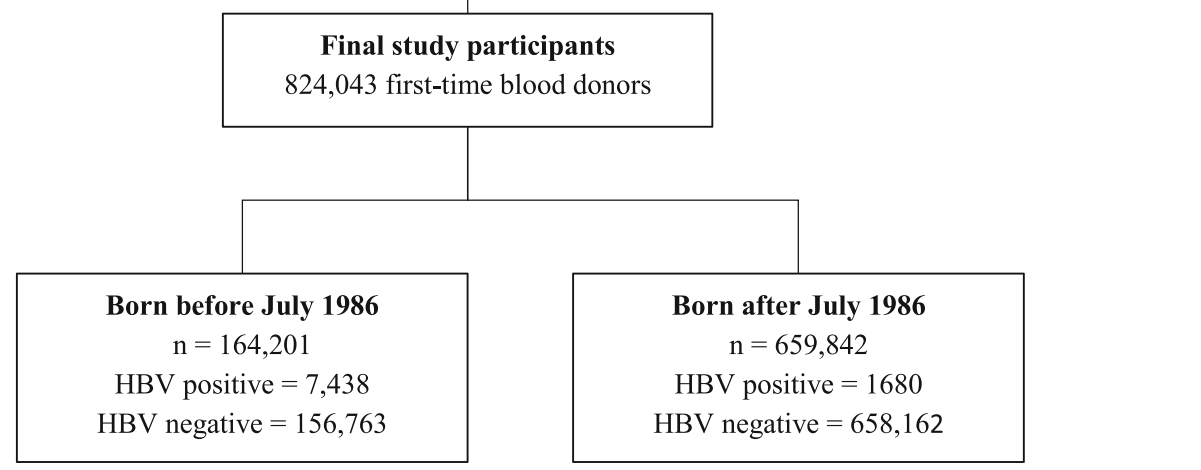

Fig. 1 Enrolment flowchart 


\section{Results}

Table 1 shows the basic demographic characteristics of first-time blood donors categorized into two cohorts: born before $(n=164,201)$ and after the July $1986 \mathrm{HBV}$ vaccination program $(n=659,842)$. Both cohorts had significant differences in HBV status, sex, age, BMI, ALT, residential area, and occupation ( $p$-value $<0.0001)$. The prevalence of $\mathrm{HBV}$ was 4.53 and $0.25 \%$ among those born before and after July 1986, respectively. Figure 2 depicts the map of Taiwan showing the prevalence of HBV infection among participants living in various regions: 2A shows the prevalence before July 1986 while 2B shows the prevalence after July 1986.

Table 2 shows the association of birth date and other factors with HBV infection. After adjusting for sex, age, blood type, BMI, ALT, residential area, and occupation, the risk of HBV infection was lower among participants born after July 1986 compared to those born before July 1986 (adjusted OR $=0.16,95 \% \mathrm{CI}=0.13-0.21$ ). Men had a higher risk of $\mathrm{HBV}$ infection compared to women (adjusted OR 1.41, 95\% CI $=1.34-1.47)$. A higher risk of HBV infection was observed among individuals who

Table 1 Basic information of the first-time blood donors stratified by birth date

\begin{tabular}{|c|c|c|c|}
\hline & Born before July 1986 & Born after July 1986 & $\overline{p \text {-value }}$ \\
\hline HBV NAT & & & $<0.001$ \\
\hline Negative & $156,763(95.47)$ & $658,162(99.75)$ & \\
\hline Positive & $7438(4.53)$ & $1680(0.25)$ & \\
\hline Sex & & & $<0.001$ \\
\hline Women & $104,463(63.62)$ & $279,276(42.32)$ & \\
\hline Men & $59,738(36.38)$ & $380,566(57.68)$ & \\
\hline Age (years) & & & $<0.001$ \\
\hline $17-29$ & $1879(1.14)$ & 654,886 (99.25) & \\
\hline $30-65$ & $162,322(98.86)$ & $4956(0.75)$ & \\
\hline Blood type & & & 0.683 \\
\hline A & $43,796(26.67)$ & $175,650(26.62)$ & \\
\hline B & $39,811(24.25)$ & $159,438(24.16)$ & \\
\hline O & $70,796(43.12)$ & $284,973(43.19)$ & \\
\hline$A B$ & 9798 (5.97) & $39,781(6.03)$ & \\
\hline BMI $\left(\mathrm{kg} / \mathrm{m}^{2}\right)$ & & & $<0.001$ \\
\hline$\leq 24$ & $91,484(55.71)$ & $462,317(70.06)$ & \\
\hline$>24$ & $72,717(44.29)$ & $197,525(29.94)$ & \\
\hline $\operatorname{ALT}(U / L)$ & $21.64 \pm 17.80$ & $17.77 \pm 16.85$ & $<0.001$ \\
\hline Residential area & & & $<0.001$ \\
\hline Northern & $57,801(35.20)$ & $178,238(27.01)$ & \\
\hline North-Central & $26,669(16.24)$ & $99,438(15.07)$ & \\
\hline Central & $32,150(19.58)$ & $144,680(21.93)$ & \\
\hline Central-South & $21,879(13.32)$ & $105,406(15.97)$ & \\
\hline Southern & $21,590(13.15)$ & $111,239(16.86)$ & \\
\hline Eastern & $3387(2.06)$ & $17,137(2.60)$ & \\
\hline Island & $725(0.44)$ & $3704(0.56)$ & \\
\hline Occupation & & & $<0.001$ \\
\hline Student & $846(0.52)$ & $419,940(63.64)$ & \\
\hline Military/civil servant/teacher & $9798(5.97)$ & $121,172(18.36)$ & \\
\hline Laborer/farmer and fisherman & $33,115(20.17)$ & $23,542(3.57)$ & \\
\hline Business/technician/specialist & $25,511(15.54)$ & $14,314(2.17)$ & \\
\hline Service worker & $34,911(21.26)$ & $37,933(5.75)$ & \\
\hline Others (including housekeepers) & $60,020(36.55)$ & $42,941(6.51)$ & \\
\hline
\end{tabular}




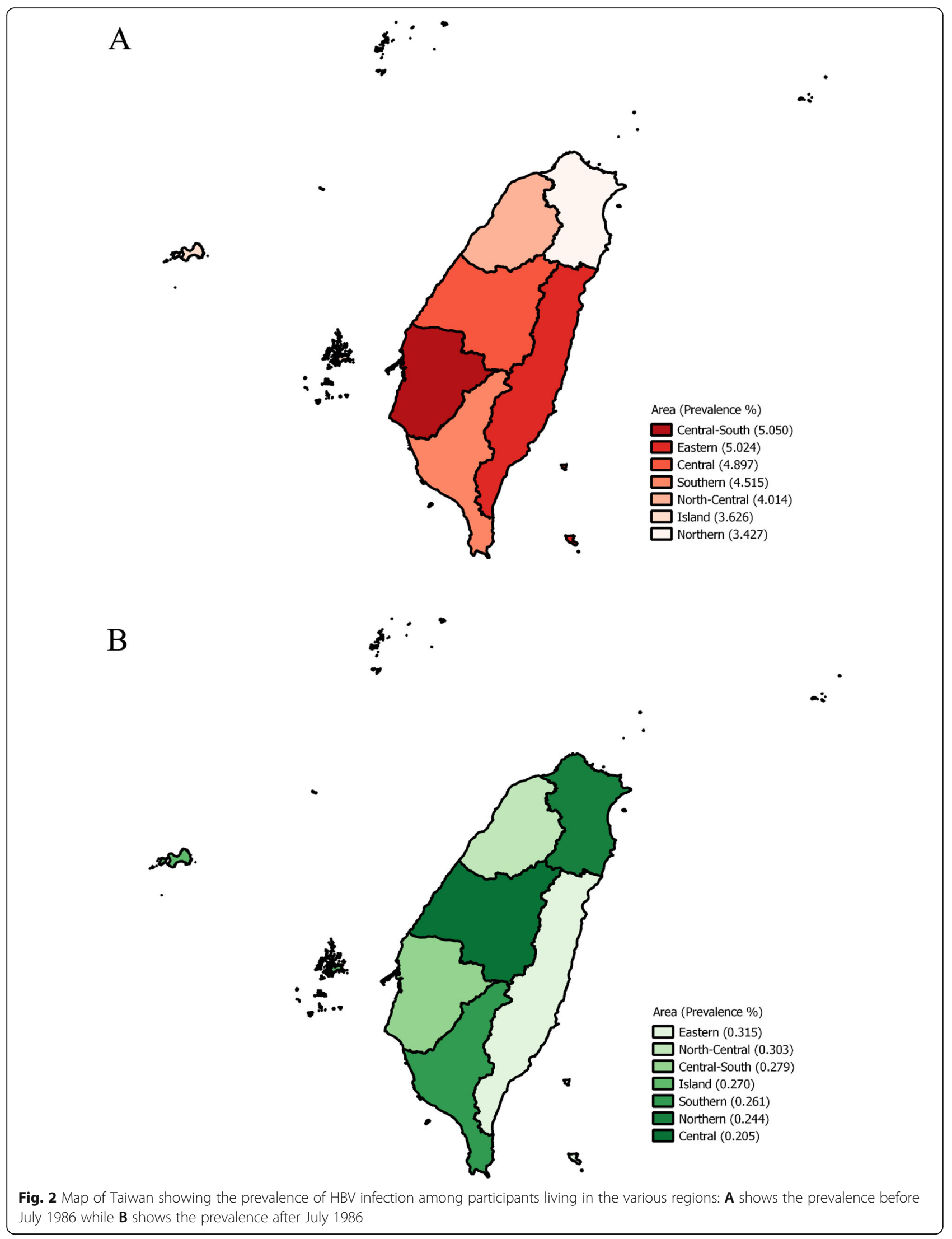


Table 2 Univariate and multivariate logistic regression models showing the association of HBV infection with sex and birth date

\begin{tabular}{|c|c|c|c|c|}
\hline & $\begin{array}{l}\text { Crude OR } \\
(95 \% \mathrm{Cl})\end{array}$ & $\begin{array}{l}p- \\
\text { value }\end{array}$ & $\begin{array}{l}\text { Adjusted OR } \\
(95 \% \mathrm{Cl})\end{array}$ & $\begin{array}{l}p- \\
\text { value }\end{array}$ \\
\hline \multicolumn{5}{|l|}{ Birth date } \\
\hline Born before July 1986 & 1 & & 1 & \\
\hline Born after July 1986 & $0.05(0.05-0.06)$ & $<0.001$ & $0.16(0.13-0.19)$ & $<0.001$ \\
\hline \multicolumn{5}{|l|}{ Sex } \\
\hline Women & 1 & & 1 & \\
\hline Men & $0.94(0.90-0.98)$ & 0.002 & $1.40(1.34-1.47)$ & $<0.001$ \\
\hline \multicolumn{5}{|l|}{ Age (years) } \\
\hline $17-29$ & 1 & & 1 & \\
\hline $30-65$ & 17.95 (17.02-18.92) & $<0.001$ & $1.66(1.35-2.05)$ & $<0.001$ \\
\hline \multicolumn{5}{|l|}{ Blood type } \\
\hline A & 1 & & 1 & \\
\hline B & $0.97(0.91-1.02)$ & 0.227 & $0.96(0.91-1.02)$ & 0.207 \\
\hline $\mathrm{O}$ & $1.01(0.96-1.07)$ & 0.621 & $1.02(0.97-1.07)$ & 0.526 \\
\hline$A B$ & $0.97(0.88-1.06)$ & 0.503 & $0.97(0.88-1.07)$ & 0.582 \\
\hline \multicolumn{5}{|l|}{ BMI $\left(\mathrm{kg} / \mathrm{m}^{2}\right)$} \\
\hline$\leq 24$ & 1 & & 1 & \\
\hline$>24$ & $1.99(1.91-2.08)$ & $<0.001$ & $1.08(1.04-1.13)$ & $<0.001$ \\
\hline $\operatorname{ALT}(\mathrm{U} / \mathrm{L})$ & $1.01(1.01-1.01)$ & $<0.001$ & $1.01(1.01-1.01)$ & $<0.001$ \\
\hline \multicolumn{5}{|l|}{ Residential area } \\
\hline Northern & 1 & & 1 & \\
\hline North-Central & $1.05(0.98-1.12)$ & 0.143 & $1.16(1.08-1.24)$ & $<0.001$ \\
\hline Central & $1.02(0.96-1.08)$ & 0.471 & $1.28(1.20-1.36)$ & $<0.001$ \\
\hline Central-South & $1.06(0.99-1.13)$ & 0.069 & $1.39(1.30-1.48)$ & $<0.001$ \\
\hline Southern & $0.92(0.86-0.98)$ & 0.012 & $1.24(1.16-1.33)$ & $<0.001$ \\
\hline Eastern & $1.03(0.90-1.18)$ & 0.667 & $1.41(1.22-1.62)$ & $<0.001$ \\
\hline Island & $0.76(0.55-1.05)$ & 0.098 & $1.03(0.74-1.43)$ & 0.865 \\
\hline \multicolumn{5}{|l|}{ Occupation } \\
\hline Service worker & 1 & & 1 & \\
\hline Student & $0.06(0.05-0.06)$ & $<0.001$ & $0.29(0.26-0.33)$ & $<0.001$ \\
\hline Military/civil servant/teacher & $0.25(0.23-0.27)$ & $<0.001$ & $0.69(0.63-0.75)$ & $<0.001$ \\
\hline Laborer/farmer and fisherman & $1.43(1.35-1.53)$ & $<0.001$ & $1.03(0.96-1.10)$ & 0.447 \\
\hline Business/technician/specialist & $1.01(0.93-1.09)$ & 0.810 & $0.76(0.71-0.83)$ & $<0.001$ \\
\hline Others (including housekeepers) & $1.07(1.01-1.14)$ & 0.027 & $0.93(0.88-0.99)$ & 0.027 \\
\hline
\end{tabular}

were 30-65 years old compared to those who were 1729 years old (adjusted OR $=1.66,95 \% \mathrm{CI}=1.35-2.05$ ) and those with a BMI $>24 \mathrm{~kg} / \mathrm{m}^{2}$ compared to $\mathrm{BMI} \leq 24$ $\mathrm{kg} / \mathrm{m}^{2}$ (adjusted $\mathrm{OR}=1.08,95 \% \mathrm{CI}=1.04-1.13$ ). ALT was also associated with a higher risk of HBV infection (adjusted OR $=1.01,95 \% \mathrm{CI}=1.01-1.01$ ). With reference to the northern region, the risk of $\mathrm{HBV}$ was significantly higher among those who lived in the north-central, central, central-southern, southern, and eastern regions. Noteworthy, the highest risk was observed among those who lived in the eastern region. The adjusted ORs; 95\%
CIs were $1.16 ; 1.08-1.24,1.28 ; 1.20-1.36,1.39 ; 1.30-$ $1.48,1.24 ; 1.16-1.33$, and $1.41 ; 1.22-1.62$, corresponding to the north-central, central, central-southern, southern, and eastern regions. Based on occupation (reference group: service workers), the risk of $\mathrm{HBV}$ infection was significantly lower among various occupations. The lowest risk was observed among students (adjusted OR = 0.29 , 95\% CI $=0.26-0.33$ ), followed by military workers/ civil servants/teachers $(\mathrm{OR}=0.69,95 \% \mathrm{CI}=0.63-0.75)$.

Table 3 illustrates the risk of $\mathrm{HBV}$ infection among donors born before and after the $1986 \mathrm{HBV}$ vaccination 
Table 3 Multivariate logistic regression analysis showing the risk of HBV infection stratified by birth date

\begin{tabular}{|c|c|c|}
\hline & $\begin{array}{l}\text { Born before July } 1986 \\
\text { OR }(95 \% \mathrm{Cl})\end{array}$ & $\begin{array}{l}\text { Born after July } 1986 \\
\text { OR }(95 \% \mathrm{Cl})\end{array}$ \\
\hline \multicolumn{3}{|l|}{ Sex } \\
\hline Women & 1 & 1 \\
\hline Men & $1.47(1.40-1.55)$ & $1.15(1.02-1.29)$ \\
\hline \multicolumn{3}{|l|}{ Age (years) } \\
\hline $17-29$ & 1 & 1 \\
\hline $30-65$ & $1.59(1.21-2.09)$ & $1.78(1.29-2.46)$ \\
\hline \multicolumn{3}{|l|}{ Blood type } \\
\hline A & 1 & 1 \\
\hline B & $0.97(0.91-1.04)$ & $0.94(0.82-1.07)$ \\
\hline $\mathrm{O}$ & $1.03(0.97-1.09)$ & $0.96(0.85-1.08)$ \\
\hline$A B$ & $0.97(0.87-1.08)$ & $0.99(0.79-1.22)$ \\
\hline \multicolumn{3}{|l|}{ BMI $\left(\mathrm{kg} / \mathrm{m}^{2}\right)$} \\
\hline$\leq 24$ & 1 & 1 \\
\hline$>24$ & $1.12(1.07-1.18)$ & $0.91(0.82-1.02)$ \\
\hline $\mathrm{ALT}(\mathrm{U} / \mathrm{L})$ & $1.01(1.01-1.01)$ & $1.01(1.01-1.01)$ \\
\hline \multicolumn{3}{|l|}{ Residential area } \\
\hline Northern & 1 & 1 \\
\hline North-Central & $1.13(1.05-1.22)$ & $1.25(1.08-1.46)$ \\
\hline Central & $1.40(1.31-1.49)$ & $0.83(0.72-0.96)$ \\
\hline Central-South & $1.44(1.34-1.55)$ & $1.17(1.01-1.36)$ \\
\hline Southern & $1.29(1.20-1.39)$ & $1.06(0.91-1.23)$ \\
\hline Eastern & $1.42(1.21-1.66)$ & $1.32(0.99-1.76)$ \\
\hline Island & $1.01(0.68-1.49)$ & $1.03(0.55-1.93)$ \\
\hline \multicolumn{3}{|l|}{ Occupation } \\
\hline Service worker & 1 & 1 \\
\hline Student & $0.45(0.28-0.71)$ & $0.25(0.22-0.30)$ \\
\hline Military/civil servant/teacher & $0.61(0.54-0.70)$ & $0.71(0.60-0.85)$ \\
\hline Laborer/farmer and fisherman & $1.02(0.95-1.09)$ & $1.11(0.91-1.37)$ \\
\hline Business/technician/specialist & $0.78(0.72-0.85)$ & $0.52(0.38-0.73)$ \\
\hline Others (including housekeepers) & $0.98(0.92-1.05)$ & $0.52(0.42-0.64)$ \\
\hline
\end{tabular}

Birth date* ${ }^{*}$ sex $p$-value $=0.0067$

program. Men had a higher risk of HBV infection than women in both birth cohorts. The adjusted ORs, 95\% CIs were 1.47, 1.40-1.55 for those born before July 1986 and $1.15,1.02-1.29$ for those born after July 1986 . There was a significant interaction between birth date and sex $(p$-value $=0.0067)$. Compared to participants aged 1729 years, those aged $30-65$ years had a higher risk of HBV infection. The adjusted ORs; 95\% CIs were 1.59; 1.21-2.09 for those born before and 1.78; $1.29-2.46$ for those born after July 1986 . The risk was also higher among those born before July 1986 with BMI $>24 \mathrm{~kg} / \mathrm{m}^{2}$ compared to $\mathrm{BMI} \leq 24 \mathrm{~kg} / \mathrm{m}^{2}$ (adjusted OR; $95 \% \mathrm{CI}=$ 1.12 ; 1.07-1.18). For those born before July 1986, the highest risk of HBV was observed among those who lived in the central-southern region, followed by the eastern region (reference: the northern region). The adjusted OR, 95\% CI was 1.44, 1.34-1.55 for the centralsouthern region and 1.42, 1.21-1.66 for the eastern region. For those born after July 1986, the highest (though not significant) risk was in the eastern (adjusted OR = $1.32,95 \% \mathrm{CI}=0.99-1.76$ ), followed by the north-central region $(\mathrm{OR}=1.25,95 \% \mathrm{CI}=1.08-1.46)$. Of note, the risk of $\mathrm{HBV}$ was significantly lower among those born after July 1986 who lived in the central region $(\mathrm{OR}=0.83$, 95\% CI, 0.72-0.96). In terms of occupation (reference group: service workers), students had the lowest risk of 
HBV infection (adjusted OR, 95\% CI $=0.45,0.28-0.71$ for those born before July 1986 and $0.25,0.22-0.30$ for those born after July 1986).

Table 4 shows the results of multiple logistic regression analysis using a combination of birth date and sex. Compared to the reference group (born before 1986 and the female sex), the risk of HBV infection was higher among men who were born before July $1986(\mathrm{OR}=1.44$, $95 \% \mathrm{CI}=1.37-1.52)$ but lower among both men $(\mathrm{OR}=$ $0.21,95 \% \mathrm{CI}=0.17-0.26)$ and women $(\mathrm{OR}=0.17,95 \%$ $\mathrm{CI}=0.14-0.22)$ born after July 1986 .

Table 4 Odds ratios for HBV infection based on the combination of sex and birth date

\begin{tabular}{|c|c|c|}
\hline & OR $(95 \% \mathrm{Cl})$ & $p$-value \\
\hline \multicolumn{3}{|l|}{ Birth date and sex } \\
\hline Born before July 1986, women & 1 & \\
\hline Born before July 1986, men & $1.44(1.37-1.52)$ & $<0.001$ \\
\hline Born after July 1986, women & $0.17(0.14-0.22)$ & $<0.001$ \\
\hline Born after July 1986, men & $0.21(0.17-0.26)$ & $<0.001$ \\
\hline \multicolumn{3}{|l|}{ Age } \\
\hline $17-29$ & 1 & \\
\hline $30-65$ & $1.65(1.34-2.04)$ & $<0.001$ \\
\hline \multicolumn{3}{|l|}{ Blood type } \\
\hline A & 1 & \\
\hline B & $0.96(0.91-1.02)$ & 0.206 \\
\hline $\mathrm{O}$ & $1.02(0.97-1.07)$ & 0.527 \\
\hline$A B$ & $0.97(0.88-1.07)$ & 0.580 \\
\hline \multicolumn{3}{|l|}{ BMl } \\
\hline$\leq 24 \mathrm{~kg} / \mathrm{m}^{2}$ & 1 & \\
\hline$>24 \mathrm{~kg} / \mathrm{m}^{2}$ & $1.08(1.03-1.13)$ & 0.001 \\
\hline $\mathrm{ALT}(\mathrm{U} / \mathrm{L})$ & $1.01(1.01-1.01)$ & $<0.001$ \\
\hline \multicolumn{3}{|l|}{ Residential area } \\
\hline Northern & 1 & \\
\hline North-Central & $1.16(1.08-1.24)$ & $<0.001$ \\
\hline Central & $1.28(1.21-1.36)$ & $<0.001$ \\
\hline Central-South & $1.39(1.30-1.49)$ & $<0.001$ \\
\hline Southern & $1.25(1.16-1.33)$ & $<0.001$ \\
\hline Eastern & $1.41(1.22-1.61)$ & $<0.001$ \\
\hline Island & $1.03(0.74-1.43)$ & 0.872 \\
\hline \multicolumn{3}{|l|}{ Occupation } \\
\hline Service worker & 1 & \\
\hline Student & $0.29(0.26-0.32)$ & $<0.001$ \\
\hline Military/civil servant/teacher & $0.70(0.64-0.77)$ & $<0.001$ \\
\hline Laborer/farmer and fisherman & $1.02(0.96-1.09)$ & 0.505 \\
\hline Business/technician/specialist & $0.76(0.71-0.83)$ & $<0.001$ \\
\hline Others (including housekeepers) & $0.94(0.88-0.99)$ & 0.044 \\
\hline
\end{tabular}

\section{Discussion}

In the current study, the 6-year prevalence of HBV (based on NAT) among first-time blood donors was $1.1 \%$. We observed a decrease in HBV infection from $4.53 \%$ among first-time donors born before the July 1986 vaccination program to $0.25 \%$ among those born after the program. Statistics from the Taiwan Blood Services Foundation showed a decrease in the percentage of first-time donors (from $15.66 \%$ in 2010 to $12.8 \%$ in 2019). Moreover, the average blood donation rate between 2013 and 2018 was just about 7.5\% [28]. Because some eligible blood donors are aging, there is a need to recruit more first-time donors to ensure the sustainability of blood supply [29]. The decrease in HBV infection after the July 1986 vaccination program observed in the current study reflects an increase in the percentage of eligible first-time donors as well as first-time donors eligible for subsequent blood donations.

HBV is a major cause of hepatocellular carcinoma [1]. To decrease the risk of HBV infection, the Taiwan government and health care workers implemented the universal HBV vaccination program in 1984 [30]. It should be noted that Taiwan was the first country to launch the HBV vaccination program in the world [11]. This preventive effort effectively reduced the incidence of $\mathrm{HBV}$ in Taiwan [31] and converted the island from a hyperto a low-endemic region [14]. Hepatitis B vaccination in infants also reduced hepatocellular carcinoma risk in both Taiwanese children and adults [32].

A previous study reported the prevalence of $4.1 \%$ for acute and $1.4 \%$ for chronic HBV infection in Taiwanese adults who were fully vaccinated (completed a four-dose plasma-derived HBV vaccination schedule) during their infancy [33]. In the current study, the prevalence of HBV among the supposed vaccinated group (born after July 1986 ) was $0.25 \%$. Some of the reasons for this difference could be because those with a personal history of surgery or blood transfusion were not eligible for blood donation and were, therefore, not included in our final analyses. Moreover, all high-risk individuals (those who had sex with viral hepatitis patients or were exposed to blood/body fluids) and those who had a diagnosis of viral hepatitis in the past year were not eligible for blood donation. NSAIDs have anti-inflammatory properties and could reduce the risk of chronic neoplastic progression [34]. Moreover, they could suppress viral replication through the inhibition of prostaglandin E2 (PGE2) [35]. Taking such medications could mean that an individual might have been previously exposed to HBV and was, therefore, not eligible for blood donation.

The proportion of men with positive HBV NAT before and after the implementation of the HBV vaccination program was higher than women. These findings are congruent to those previously reported among 
Taiwanese after a follow-up of over 18 years [36]. Serum levels of HBsAg are also higher in men than women [37, 38]. Moreover, after HBV vaccination, men have higher titers of anti-HBs antibodies than women [36]. The sex disparity in HBV infection is shaped by genetic factors and mainly regulated by sex hormones [39]. The main male hormone (androgen) has immune-suppressing effects while the female hormone (estrogen) has immuneenhancing properties. Therefore, the higher risk in men and lower risk in women could be attributed to the abundance of androgens and estrogens which could respectively suppress and promote immune responses to infections [39-41]. The X chromosome is believed to be enriched with genes that have immune responses [42, 43]. Therefore, the lower risk of HBV in women could also be attributed to the presence of two $\mathrm{X}$ chromosomes in women. Furthermore, a variant of the HBV receptor gene, sodium taurocholate co-transporting polypeptide (NTCP) was associated with a lower risk of HBV infection among Taiwanese women [44].

HBV infection was higher among older first-time donors compared to their younger counterparts. This could be because older individuals may have not been vaccinated at birth. Besides, the deterioration of the immune system termed, immunosenescence is related to aging [45]. As people get older, their immune systems become compromised making them vulnerable to infections.

Compared to normal-weight individuals, obese people have a higher likelihood of bacterial, viral, and fungal infections [46]. Moreover, poor response to hepatitis B vaccination is common among obese individuals with a compromised immune system [46]. Loss of response to HBV immunization is also related to obesity [47]. One reason could be due to leptin which is produced by fat cells. Abnormal levels of this hormone could induce systemic and B cell-intrinsic inflammation, weaken $\mathrm{T}$ cell responses, and impair the division and proliferation of lymphocytes in obese people, thereby increasing their risk of HBV infection [47].

Determination of blood groups is very important before a blood transfusion because blood groups are associated with certain diseases [48]. HBV infection was not associated with blood group in the current study. Previous findings on the association of blood groups with HBV have not been coherent. For instance, in a metaanalysis, blood group B was associated with a lower risk of HBV infection while blood group $\mathrm{O}$ was not significantly associated with HBV infection among Asians [49]. In another study, blood group $\mathrm{O}$ was associated with a lower risk of HBV infection among Iranian blood donors [50]. On the contrary, blood group $\mathrm{O}$ was associated with a higher risk of HBV among Chinese [23]. The discrepancy between our study and previous studies could be due to different prevalence rates, demographic characteristics, and different ratios of blood types. Further investigations of this relationship are warranted.

In this study, we categorized hairdressers and healthcare workers as service workers and used them as the reference group because they are high-risk individuals. Besides, the sample sizes in this group were comparable in both birth cohorts (before and after 1986). The risk of HBV is higher among hairdressers [51] and healthcare workers [52], probably because of high exposure to sharp objects [53].

In our study, living in eastern Taiwan was associated with the highest risk of HBV in most scenarios. In a previous study, the prevalence of HBV was higher among the indigenous people than the other Taiwanese populations [54]. Most indigenous people live in the eastern part of the country like Taitung and Hualien which have insufficient medical facilities compared to other parts [55]. Interestingly, we found that living in Central Taiwan was associated with a higher risk of HBV among those who were born before July 1986. However, living in the same area was associated with a lower risk among individuals who were born after July 1989. We cannot comprehensively explain the mechanism underlying the observed associations and therefore, recommend further investigations to clarify our findings.

The strength of this study is its relatively large sample size. However, there are some limitations. First, even though the prevalence of hepatitis $\mathrm{B}$ infection in smokers is higher than in nonsmokers [56], we did determine the association of smoking with HBV because the health questionnaires did not contain information on cigarette smoking. Second, marital status, education level, and the family history of HBV are some major risk factors of HBV infection [57]. To follow the "Personal Information Protection Act", the marital status and education level were not included in the blood donor registration form and therefore, these factors were not evaluated. The health questionnaire did not also have information on the family history of HBV. Third, it is reported that about $77 \%$ of $\mathrm{HBsAg}$-positive individuals under 30 years were born to $\mathrm{HBsAg}$-positive mothers [58]. However, our questionnaires did not contain information on participants' mothers' HBV status or vaccination history. Therefore, we could not determine what proportion of the donors were born to HBsAg-positive mothers. Lastly, we did not know exactly how many people were vaccinated from July 1986. However, it has been shown that at least $90 \%$ of children in Taiwan born after 1986 received vaccination at birth [59].

\section{Conclusions}

In conclusion, the prevalence of HBV among first-time blood donors decreased from $4.2 \%$ before the July 1986 HBV vaccination program to $0.25 \%$ after the program, suggesting that more first-time blood donors could be 
eligible for subsequent blood donations. The risk of HBV was lower among those who were born after compared to those who were born before July 1986. In both cohorts, the risk was high in men relative to women. The protective effect among those born after July 1986 was higher in women than men. Age $\geq 30$ years, BMI $\geq$ $24 \mathrm{~kg} / \mathrm{m}^{2}$, living in the eastern part of the country, and occupations other than students were associated with a higher risk of HBV. To avoid HBV infection, the population should be educated on the importance of taking appropriate preventive measures especially vaccination.

\section{Abbreviations \\ HBV: Hepatitis B virus; OR: Odds ratio; Cl: Confidence interval; \\ HCC: Hepatocellular carcinoma; HBsAg: HBV surface antigen; NAT: Nucleic amplification test; BMI: Body mass index; Hb: Hemoglobin; TTVI: Transfusion- transmitted viral infection; HCV: Hepatitis C; ALT: Alanine aminotransferase}

\section{Acknowledgments}

We would like to thank all the blood donors and the staff of Taipei, Hsinchu, Taichung, Tainan, and Kaohsiung Blood Centers.

\section{Authors' contributions}

Conceptualization: Hsuan-Hui Wang, Data curation: Rong- Chiou Jau and Shu-Lung Sun, Investigation: Hsuan-Hui Wang, Data analysis or interpretation: Hsuan-Hui Wang, Shu-Lung Sun, Rong-Chiou Jau, Disline Manli Tantoh, ShuYi Hsu, Oswald Ndi Nfor, Pei-Hsin Chen, Wen-Hsiu Liu, Jiunn-Liang Ko, and Yung-Po Liaw, Methodology: Hsuan-Hui Wang, Shu-Lung Sun, Rong-Chiou Jau, Disline Manli Tantoh, Shu-Yi Hsu, Oswald Ndi Nfor, Pei-Hsin Chen, WenHsiu Liu, Jiunn-Liang Ko, and Yung-Po Liaw, Writing-original draft: Hsuan-Hui Wang, Writing-review and editing: Hsuan-Hui Wang, Shu-Lung Sun, RongChiou Jau, Disline Manli Tantoh, Shu-Yi Hsu, Oswald Ndi Nfor, Pei-Hsin Chen, Wen-Hsiu Liu, Jiunn-Liang Ko, and Yung-Po Liaw. The authors read and approved the final manuscript.

\section{Funding}

This research was supported by the Taiwan Blood Services Foundation (PM108-TC-197) and partly by the Ministry of Science and Technology (MOST), Taiwan (MOST 109-2121-M-040-002, MOST 110-2121-M-040-002,MOST 1092811-M-040-500 andMOST 110-2811-M-040-001).

\section{Availability of data and materials}

The data that support the findings of this study are available from the Taiwan Blood Services Foundation (TBSF) but restrictions apply to the availability of these data, which were used under license for the current study, and so are not publicly available. Data are however available from Professor Yung Po Liaw (Email address: Liawyp@csmu.edu.tw, Tel: + 886424730022 ext. 12102; fax: +886423248179$)$ upon reasonable request and with permission of Taiwan Blood Services Foundation (TBSF).

\section{Declarations}

\section{Ethics approval and consent to participate}

All methods were carried out following relevant guidelines and regulations. Informed consent was obtained from all participants. Ethical approval was obtained from the Ethical Review Board of the Taiwan Blood Services Foundation (PM-108-TC-197)

\section{Consent for publication}

Not applicable.

\section{Competing interests}

The authors declare that they have no competing interests.

\section{Author details}

'Taichung Blood Center, Taiwan Blood Services Foundation, Taichung, Taiwan. ${ }^{2}$ Taiwan Blood Services Foundation, Taipei, Taiwan. ${ }^{3}$ Department of Medical Imaging, Chung Shan Medical University Hospital, Taichung, Taiwan.
${ }^{4}$ Department of Public Health and Institute of Public Health, Chung Shan Medical University, No. 110, Sec. 1 Jianguo N. Rd, Taichung 40201, Taiwan. ${ }^{5}$ Institute of Medicine, Chung Shan Medical University, No. 110, Sec. 1 Jianguo N. Rd, Taichung 40201, Taiwan. ${ }^{6}$ Department of Medical Oncology and Chest Medicine, Chung Shan Medical University Hospital, Taichung, Taiwan. ${ }^{7}$ Medical Imaging and Big Data Center, Chung Shan Medical University Hospital, Taichung, Taiwan.

Received: 12 March 2021 Accepted: 21 September 2021

Published online: 09 October 2021

\section{References}

1. Lu SN, Su WW, Yang SS, Chang TT, Cheng KS, Wu JC, et al. Secular trends and geographic variations of hepatitis $B$ virus and hepatitis $C$ virusassociated hepatocellular carcinoma in Taiwan. Int J Cancer. 2006;119(8): 1946-52. https://doi.org/10.1002/ijc.22045.

2. Schweitzer A, Horn J, Mikolajczyk RT, Krause G, Ott JJ. Estimations of worldwide prevalence of chronic hepatitis B virus infection: a systematic review of data published between 1965 and 2013. Lancet. 2015;386(10003): 1546-55. https://doi.org/10.1016/S0140-6736(15)61412-X.

3. Liu CJ, Lo SC, Kao JH, Tseng PT, Lai MY, Ni YH, et al. Transmission of occult hepatitis B virus by transfusion to adult and pediatric recipients in Taiwan. J Hepatol. 2006;44(1):39-46. https://doi.org/10.1016/j.jhep.2005.06.016.

4. Gerlich WH. Prophylactic vaccination against hepatitis B: achievements, challenges and perspectives. Med Microbiol Immunol. 2015;204(1):39-55. https://doi.org/10.1007/s00430-014-0373-y.

5. $\mathrm{Ni} \mathrm{YH}$, Chang MH, Wu JF, Hsu HY, Chen HL, Chen DS. Minimization of hepatitis B infection by a 25-year universal vaccination program. J Hepatol. 2012;57(4):730-5. https://doi.org/10.1016/j.jhep.2012.05.021.

6. Ott JJ, Stevens GA, Groeger J, Wiersma ST. Global epidemiology of hepatitis $B$ virus infection: new estimates of age-specific HBsAg seroprevalence and endemicity. Vaccine. 2012;30(12):2212-9. https://doi.org/10.1016/j.vaccine.2 011.12.116.

7. Tang X, Allain JP, Wang H, Rong X, Chen J, Huang K, et al. Incidence of hepatitis $B$ virus infection in young Chinese blood donors born after mandatory implementation of neonatal hepatitis B vaccination nationwide. J Viral Hepat. 2018:25(9):1008-16. https://doi.org/10.1111/jvh.12901.

8. Sung JL. Hepatitis B virus infection and its sequelae in Taiwan. Gastroenterol Jpn. 1984;19(4):363-6. https://doi.org/10.1007/BF02779126.

9. Stevens CE, Beasley RP, Tsui J, Lee W-C. Vertical transmission of hepatitis B antigen in Taiwan. N Engl J Med. 1975;292(15):771-4. https://doi.org/10.1 056/NEJM197504102921503.

10. Chen D, Sung J. Hepatitis B virus infection and chronic liver disease in Taiwan. Acta hepato-gastroenterologica. 1978;25(6):423-30.

11. Chen D-S, Hsu NH-M, Sung J-L, Hsu T-C, Hsu S-T, Kuo Y-T, et al. A mass vaccination program in Taiwan against hepatitis $B$ virus infection in infants of hepatitis B surface antigen—carrier mothers. Jama. 1987;257(19):2597603. https://doi.org/10.1001/jama.1987.03390190075023.

12. Tsai Y-T, Lo K-J, Lee S-D, Wang J-Y, Wu J-C, Chang CY, et al. A comparison of immunogenicity of reduced doses of hepatitis $B$ vaccine in infants born to noncarrier mothers in Taiwan. 中華民國消化系醫學會雜誌. 1987;4(2): $56-62$.

13. Su FH, Chen JD, Cheng SH, Sung KY, Jeng JJ, Chu FY. Waning-off effect of serum hepatitis B surface antibody amongst Taiwanese university students: 18 years post-implementation of Taiwan's national hepatitis B vaccination programme. J Viral Hepat. 2008;15(1):14-9. https://doi.org/10.1111/j.1365-2 893.2007.00890.x.

14. Hu YC, Yeh CC, Chen RY, Su CT, Wang WC, Bai CH, et al. Seroprevalence of hepatitis $B$ virus in Taiwan 30 years after the commencement of the national vaccination program. PeerJ. 2018;6:e4297. https://doi.org/10.7717/ peerj.4297.

15. Yang $S$, Tian $G$, Cui Y, Ding C, Deng $M, Y u$, et al. Factors influencing immunologic response to hepatitis B vaccine in adults. Sci Rep. 2016;6(1):112. https://doi.org/10.1038/srep27251

16. Anwar MS, Siddiqi GM, Haq S, Khokhar G, Jaffery G. Association of blood group types to hepatitis B and hepatitis C virus infection. Biomedica. 2011; 27(12):57-61.

17. Tyagi S, Tyagi A. Possible correlation of transfusion transmitted diseases with Rh type and ABO blood group system. J Clin Diagn Res. 2013:7(9): 1930-1. https://doi.org/10.7860/JCDR/2013/6002.3360. 
18. Mandell GL. Douglas. Principles and practice of infectious disease. In: Churchill; 2000.

19. Rios M, Bianca C. The role of blood group antigens in infectious diseases. In: Seminars in hematology: 2000: Elsevier; 2000. p. 177-85.

20. Zhou Y, Zhou Q, Lin Q, Chen R, Gong Y, Liu Y, et al. Evaluation of risk factors for extrahepatic cholangiocarcinoma: ABO blood group, hepatitis B virus and their synergism. Int J Cancer. 2013;133(8):1867-75. https://doi. org/10.1002/ijc.28196.

21. Paré G, Chasman DI, Kellogg M, Zee RY, Rifai N, Badola S, et al. Novel association of ABO histo-blood group antigen with soluble ICAM-1: results of a genome-wide association study of 6,578 women. PLoS Genet. 2008; 4(7):e1000118. https://doi.org/10.1371/journal.pgen.1000118.

22. SB KV, Bandi S, Kondareddy S, Madithadu A. Association of ABO and Rh blood groups to HBV, HCV infections among blood donors in a blood bank of tertiary care teaching hospital in southern India: a retrospective study. Int J Res Med Sci. 2015;3(7):1672-6. https://doi.org/10.18203/2320-6012.ijrms201 50249.

23. Liu J, Zhang S, Liu M, Wang Q, Shen H, Zhang Y. Distribution of ABO/Rh blood groups and their association with hepatitis B virus infection in 3.8 million Chinese adults: a population-based cross-sectional study. J Viral Hepat. 2018;25(4):401-11. https://doi.org/10.1111/jvh.12829.

24. Merican I, Guan R, Amarapuka D, Alexander MJ, Chutaputti A, Chien RN, et al. Chronic hepatitis B virus infection in Asian countries. J Gastroenterol Hepatol. 2000;15(12):1356-61. https://doi.org/10.1046/j.1440-1746.2000.01 50121356.x.

25. Ministry of the Interior TROCThOEtSoaAS: accessed on 10 Apr 2018.

26. Seed $C$. Value of retaining $H B S A g$ donor screening where HBV NAT and anti-HB c donor screening apply. ISBT Science Series. 2018;13(1):70-5. https://doi.org/10.1111/voxs.12368.

27. Blanco S, Balangero MC, Valle MC, Montini OL, Carrizo LH, Gallego SV. Usefulness of nucleic acid testing to reduce risk of hepatitis $B$ virus transfusion-transmitted infection in Argentina: high rate of recent infections. Transfusion. 2017;57(3pt2):816-22.

28. Foundation AROTBS: 2019.

29. Goldman M, Steele WR, Di Angelantonio E, van den Hurk K, Vassallo RR, Germain $\mathrm{M}$, et al. Biomedical excellence for safer transfusion collaborative I: comparison of donor and general population demographics over time: a BEST collaborative group study. Transfusion. 2017;57(10):2469-76. https:// doi.org/10.1111/trf.14307.

30. Chen DS. Fighting against viral hepatitis: lessons from Taiwan. Hepatology. 2011;54(2):381-92. https://doi.org/10.1002/hep.24500.

31. Control TCfD: access on 30 Jul 2016.

32. Chang MH, You SL, Chen CJ, Liu CJ, Lai MW, Wu TC, et al. Long-term effects of hepatitis B immunization of infants in preventing liver Cancer. Gastroenterology. 2016;151(3):472-80 e471. https://doi.org/10.1053/j.gastro.2 016.05.048.

33. Su FH, Cheng SH, Li CY, Chen JD, Hsiao CY, Chien CC, et al. Hepatitis B seroprevalence and anamnestic response amongst Taiwanese young adults with full vaccination in infancy, 20 years subsequent to national hepatitis B vaccination. Vaccine. 2007;25(47):8085-90. https://doi.org/10.1016/j.vaccine.2 007.09.013.

34. Kim AK, Dziura J, Strazzabosco M. Nonsteroidal anti-inflammatory drug use, chronic liver disease, and hepatocellular carcinoma: the egg of Columbus or another illusion? Hepatology. 2013;58(2):819-21. https://doi.org/10.1002/ hep.26498.

35. Ray N, Bisher ME, Enquist LW. Cyclooxygenase-1 and -2 are required for production of infectious pseudorabies virus. J Virol. 2004;78(23):12964-74. https://doi.org/10.1128/JVI.78.23.12964-12974.2004.

36. Su FH, Chen JD, Cheng SH, Lin CH, Liu YH, Chu FY. Seroprevalence of hepatitis-B infection amongst Taiwanese university students 18 years following the commencement of a national hepatitis-B vaccination program. J Med Virol. 2007;79(2):138-43. https://doi.org/10.1002/jmv.20771.

37. Tsay P-K, Tai D-I, Chen Y-M, Yu C-P, Wan S-Y, Shen Y-J, et al. Impact of gender, viral transmission and aging in the prevalence of hepatitis B surface antigen. Chang Gung Med J. 2009;32(2):155-64.

38. Chen C-J, Yang H-I, Su J, Jen C-L, You S-L, Lu S-N, et al. Risk of hepatocellular carcinoma across a biological gradient of serum hepatitis B virus DNA level. JAMA. 2006;295(1):65-73. https://doi.org/10.1001/jama.295.1.65.

39. Ruggieri A, Gagliardi MC, Anticoli S. Sex-dependent outcome of hepatitis B and $C$ viruses infections: synergy of sex hormones and immune responses? Front Immunol. 2018;9:2302. https://doi.org/10.3389/fimmu.2018.02302.
40. Fischer A, Notarangelo LD, Neven B, Cavazzana M, Puck JM. Severe combined immunodeficiencies and related disorders. Nat Rev Dis Primers. 2015;1(1):1-18. https://doi.org/10.1038/nrdp.2015.61.

41. Giefing-Kroll C, Berger P, Lepperdinger G, Grubeck-Loebenstein B. How sex and age affect immune responses, susceptibility to infections, and response to vaccination. Aging Cell. 2015;14(3):309-21. https://doi.org/10.1111/a cel.12326.

42. Fink AL, Engle K, Ursin RL, Tang WY, Klein SL. Biological sex affects vaccine efficacy and protection against influenza in mice. Proc Natl Acad Sci U S A. 2018;115(49):12477-82. https://doi.org/10.1073/pnas.1805268115.

43. Sarmiento L, Svensson J, Barchetta I, Giwercman A, Cilio CM. Copy number of the X-linked genes TLR7 and CD40L influences innate and adaptive immune responses. Scand J Immunol. 2019;90(2):e12776. https://doi.org/1 $0.1111 / \mathrm{sji} .12776$

44. Nfor ON, Wu MF, Debnath T, Lee CT, Lee W, Liu WH, et al. Hepatitis B virus infection in Taiwan: the role of NTCP rs2296651 variant in relation to sex. J Viral Hepat. 2018;25(10):1116-20. https://doi.org/10.1111/jvh.12912.

45. Nikolich-Zugich J. The twilight of immunity: emerging concepts in aging of the immune system. Nat Immunol. 2018;19(1):10-9. https://doi.org/10.1038/ s41590-017-0006-X.

46. Frasca D, Blomberg BB. The impact of obesity and metabolic syndrome on vaccination success. In: Vaccines for Older Adults: Current Practices and Future Opportunities. Volume 43, edn: Karger Publishers; 2020. p. 86-97.

47. Liu F, Guo Z, Dong C. Influences of obesity on the immunogenicity of hepatitis B vaccine. Hum Vaccin Immunother. 2017;13(5):1014-7. https://doi. org/10.1080/21645515.2016.1274475.

48. Cooling L. Blood groups in infection and host susceptibility. Clin Microbiol Rev. 2015;28(3):801-70. https://doi.org/10.1128/CMR.00109-14

49. Jing W, Zhao S, Liu J, Liu M. ABO blood groups and hepatitis B virus infection: a systematic review and meta-analysis. BMJ Open. 2020;10(1): e034114. https://doi.org/10.1136/bmjopen-2019-034114.

50. Mohammadali F, Pourfathollah A. Association of $A B O$ and Rh blood groups to blood-borne infections among blood donors in Tehran-Iran. Iran J Public Health. 2014;43(7):981-9.

51. Olusola B, Gometi E, Ogunsemowo O, Olaleye D, Odaibo G. High rate of hepatitis B virus infection among hairdressers in Ibadan, Nigeria. J Immunoassay Immunochem. 2017;38(3):322-32. https://doi.org/10.1080/1 5321819.2016.1260585.

52. Shao ER, Mboya IB, Gunda DW, Ruhangisa FG, Temu EM, Nkwama ML, et al. Seroprevalence of hepatitis B virus infection and associated factors among healthcare workers in northern Tanzania. BMC Infect Dis. 2018;18(1):474. https://doi.org/10.1186/s12879-018-3376-2.

53. Wait S, Chen D-S. Towards the eradication of hepatitis B in Taiwan. Kaohsiung J Med Sci. 2012;28(1):1-9. https://doi.org/10.1016/j.kjms.2011.10.027.

54. Huang CF, Dai CY, Chuang WL, Ho CK, Wu TC, Hou NJ, et al. HBV infection in indigenous children, 20 years after immunization in Taiwan: a community-based study. Prev Med. 2009;48(4):397-400. https://doi.org/10.1 016/j.ypmed.2009.02.002

55. Ministry of the Interior TROC: access on 09 Mar 2019.

56. Ghadir MR, Belbasi M, Heidari A, Jandagh M, Ahmadi I, Habibinejad $H$, et al. Distribution and risk factors of hepatitis $B$ virus infection in the general population of Central Iran. Hepat Mon. 2012;12(2):112-7. https://doi.org/10. 5812/hepatmon.4909.

57. Chen E-Q, Ma Y-J, Wang J, He F, Zhou T-Y, Ji Y-L, et al. Prevalence of hepatitis B virus infection in western China: epidemiological survey results of general adult population. Futur Virol. 2018;13(09):629-36. https://doi.org/1 0.2217/fvl-2018-0051.

58. Ni YH, Chang MH, Jan CF, Hsu HY, Chen HL, Wu JF, et al. Continuing decrease in hepatitis B virus infection 30 years after initiation of infant vaccination program in Taiwan. Clin Gastroenterol Hepatol. 2016;14(9):132430. https://doi.org/10.1016/..cgh.2016.04.030.

59. Ni Y-H, Chang M-H, Huang L-M, Chen H-L, Hsu H-Y, Chiu T-Y, et al. Hepatitis $B$ virus infection in children and adolescents in a hyperendemic area: 15 years after mass hepatitis B vaccination. Ann Intern Med. 2001;135(9):796800. https://doi.org/10.7326/0003-4819-135-9-200111060-00009.

\section{Publisher's Note}

Springer Nature remains neutral with regard to jurisdictional claims in published maps and institutional affiliations. 